\title{
Growth Stratification Applied to Prognosis of Diametric Structure in Araucaria Forest
}

\author{
Sylvio Péllico Netto*, Ângelo Augusto Ebling, Emanuel José Gomes de Araújo \\ Department of Forest Science, University Federal of Paraná, Curitiba, Brazil \\ Email: sylviopelliconetto@gmail.com
}

Received 20 April 2014; revised 20 May 2014; accepted 3 June 2014

Copyright (C) 2014 by authors and Scientific Research Publishing Inc.

This work is licensed under the Creative Commons Attribution International License (CC BY). http://creativecommons.org/licenses/by/4.0/

(c) (i) Open Access

\section{Abstract}

The forest management, in broad terms, covers a set of information and activities related to the growth and production of plantations or from heterogeneous forests. If on one hand forest plantation presents homogeneous dendrometric characteristics, on the other hand in heterogeneous forests such a configuration does not exist, which requires the application of essential mathematical estimates for the forest management planning, for example, the prognosis of diametric structure. In this respect, refinements can be tested in traditionally used mathematical models, aiming at more accurate results. These facts substantiate the following hypotheses: the stratification of the diameter increments can provide estimates with greater accuracy and more precise results for the prognosis. With the stratification of diameter increment made it possible to get better results for the prognosis for a 4-year period, allowing the forest manager to better work with estimators either for diameter classes as well as for the forest to be managed. Using the data structure of trees (DBH $\geq 9.5 \mathrm{~cm}$ ) of the National Forest of Sao Francisco de Paula, RS, Brazil, the diameter increment of species was stratified into four statistically different strata. Using data sampled between the years of 2000 to 2004, it was carried out prognosis for the year 2008, using the stratified and not stratified data. The estimates were compared with the observed values by the Kolmogorov-Smirnov (K-S) test, which attested goodness of fit only for the estimates from the stratified values. The prognosis estimated by means of stratified values also showed more accurate results, because the stratified variance was reduced nine times when compared with that obtained with the prognosis made without stratified data and to determine the Quotient of De Liocourt. Thus, the diameter growth stratification indicated to be effective to generate more accurate prognosis.

\section{Keywords}

Diameter Projection, Forest Management, Heterogeneous Forest

\footnotetext{
*Corresponding author.

How to cite this paper: Netto, S.P., Ebling, Â.A. and de Araújo, E.J.G. (2014) Growth Stratification Applied to Prognosis of Diametric Structure in Araucaria Forest. Journal of Applied Mathematics and Physics, 2, 753-761. 


\section{Introduction}

Brazil has the second largest forest area in the world, covering 516 million hectares and from this total $98.7 \%$ is made up of natural forests [1], which highlights the importance of the conservation and rational exploitation of forest resources, as a way to leverage the national development. However, sustainable management practices rely on studies for its effectiveness and also that enables efficiency in mechanisms traditionally employed.

Methodologies consist of mathematical models to generate prognosis, as the ratio of moving diameters, which are dependent on information related to forest dynamics [2] and allow subsidizing information for the effectuation of a rational exploitation of heterogeneous forests. However, refinements can be applied to these models, aiming at more accurate estimates [3].

Whereas stratification has the goal to reduce the variance of a sample, resulting in subpopulations with greater homogeneity [4], the application of the ratio of change for making prognosis, including the number of recruitment and mortality, which is based on the diameter growth model [5]; these facts substantiate our main hypotheses: the stratification of the diameter increments can provide estimates with greater accuracy and more precise results for the prognosis.

Although stratification of height is of great importance in phytosociological studies and in forest management and often used by managers [6], stratification of diameter is still little employed in such studies. The delimitation of strata or subpopulations, defined as a function of the species diameter growth, may also be useful in projects for rehabilitation and restoration of degraded areas, in which the choice of species will be more appropriate if it is, at our disposal, a broader knowledge about them [7]. Also relevant, the groups of species separated by growth can guide the planning of projects related to the carbon storage, as well as better clarify the use of silvicultural activities and practices demanded by the forest management.

\section{Methodology}

\subsection{Experimental Area}

The study was conducted in the National Forest of Sao Francisco de Paula, located between the coordinates $29^{\circ} 24^{\prime}$ and $29^{\circ} 27^{\prime}$ South latitude and $50^{\circ} 22^{\prime}$ and $50^{\circ} 25^{\prime}$ West longitude, in the mesoregion northeast of the State of Rio Grande do Sul, Microregion of Vacaria, in Brazil. The average altitude site is 900 meters above the sea level, ranging this value \pm 300 meters. The soils that characterize the region are classified as Haplumbrept, Argiudoll, Udorthent [8], derived from basic and acidic effusive rocks of the Serra Geral Formation [9].

In accordance with the global classification of climatic types developed by Köppen, the climate of the region is of type $\mathrm{Cfb}$, mesothermal and super humid, with mild summer and cold winter. The formation of frost is frequent, with snowfall in the colder months [10].

The predominant vegetation of the National Forest area is the Araucaria Forest or Mixed Tropical Forest, monitored by means of continuous forest inventory with the application of sampling with total replacement, which encompasses a total sample area of 10 permanent plots with an area of 1 ha $(100 \times 100 \mathrm{~m})$ each, remeasured annually since the year 2000. All arboreal individuals (trees with diameter at breast height $\geq 9.5 \mathrm{~cm}$ ) included in sample area were botanically identified and had their dendrometric information measured.

\subsection{Data Collection and Stratification}

Taking the diameters collected in a specific period, their periodic increments were calculated and subsequently the mean of the periodic increment $(\overline{M P I})$ for each species. In order to make the population of species more consistent, only those that met a minimum of 10 individuals in the sample were considered. After that it was defined the population of species $E(1,2,3, \cdots, N)$ from which a random variable $X_{i}$ was measured, the $(M P I)$ per individual of each species, such that it was characterized for each species a population of sample values $P_{i j}$, such that $i=1,2,3, \cdots, M_{j}$ individuals and $j=1,2,3, \cdots, N$ species, i.e.,

$P\left(X_{11}, X_{21}, X_{31}, \cdots, X_{M 1} ; X_{12}, X_{22}, X_{32}, \cdots, X_{M 2} ; X_{1 N}, X_{2 N}, X_{3 N}, \cdots, X_{M N}\right)$, in which the arithmetic mean and variance per species are given by $\bar{X}_{M P I, j}$ and $S_{M P I, j}^{2}$ respectively.

The stratification of growth was established taking as criterion the quartiles formalized on the basis of the arithmetic mean of the growth of species $\left(\bar{X}_{M P I}\right)$ and the standard deviation $\left(S_{M P I}\right)$. In this way, the population of species will be fractioned into $L$ strata, such that each one of them will be delimited as $E_{h}\left(1,2,3, \cdots, N_{h}\right)$, 
in that $N_{h}$ is the number of species of each stratum and, consequently, $N_{1}+N_{2}+\cdots+N_{L}=N$ and $h=1,2,3, \cdots, L$. Thus, the strata are composed respectively of $E_{j h}\left(X_{1 h}, X_{2 h}, X_{3 h}, \cdots, X_{j N L}\right)$.

This procedure of stratification was decided as demonstrated by Cochran (1963), in that, if the full range of variation of MPI's is expressed by $\left(E_{L}-E_{0}\right)$, the separation of the strata $\left(E_{h}-E_{h+1}\right)$, being taken of constant size, will minimize the sum of squares due to stratification and, consequently, it will result in the minimum stratified variance of mean, i.e., maximum accuracy by application of stratification.

It was proposed four strata for growth evaluation: $E_{1}, E_{2}, E_{3}$ and $E_{4}$, which is composed, respectively, of the smallest to the largest increments. The stratum $E_{1}$ was composed by species with periodic mean increment $(\overline{M P I})$ less than the average growth of all species minus one standard deviation $\left(E_{1}=\bar{X}_{I P D}-S_{M P I}\right)$, with mean $\left(\bar{X}_{E_{1}}\right)$ and variance $\left(S_{E_{1}}^{2}\right)$. The stratum $E_{2}$, composed by the species with higher growth than $E_{1}$ up to the limit of one standard deviation above that value $\left(E_{2}=E_{1}+S_{I P D}\right)$, with mean $\left(\bar{X}_{E_{2}}\right)$ and variance $\left(S_{E_{2}}^{2}\right)$. The same was set alongside to the third stratum $E_{3}$, composed by species of growth higher than the $E_{2}$, up to the limit of one standard deviation above that value $\left(E_{3}=E_{2}+S_{M P I}\right)$, with mean $\left(\bar{X}_{E_{3}}\right)$ and variance $\left(S_{E_{3}}^{2}\right)$. The fourth stratum $E_{4}$ is understood to have the grater values than $E_{3}$, with mean $\left(\bar{X}_{E_{4}}\right)$ and variance $\left(S_{E_{4}}^{2}\right)$. It was calculated the variance of the increments before stratification $\left(S_{M P I}^{2}\right)$ and after stratification $\left(S_{\text {est }}^{2}\right)$.

Such parameters for the stratified population will be obtained as are expressed in (1) for the stratified mean and in (2) for the stratified variance.

$$
\begin{gathered}
\bar{X}_{\text {est }}=\sum_{h=1}^{L} W_{h} \bar{X}_{E_{h}} \text { where } W_{h}=N_{h} N^{-1} \\
S_{\text {est }}^{2}=\sum_{h=1}^{L} W_{h}^{2} S_{h}^{2}
\end{gathered}
$$

\subsection{Statistical Evaluation of the Population}

The normality of the data set was checked by the Shapiro-Wilk test $(W)$, and the homogeneity of variances by Hartley test $\left(F_{\max }\right)$. If null hypotheses $H_{0}$ is rejected (normal distribution and homogenous variance), it will be applied to the data set the appropriate transformations using the method of Box and Cox, defined as:

$$
\begin{cases}y^{\lambda}=\frac{\left(y+\lambda_{2}\right)^{\lambda_{1}}-1}{\lambda_{1}} & \lambda_{1} \neq 0 \\ y^{\lambda}=\log \left(y+\lambda_{2}\right) & \lambda_{1}=0\end{cases}
$$

where:

$$
\begin{aligned}
& y^{\lambda}=\text { transformed value; } \\
& y=\text { observed value; } \\
& \lambda_{1}=\text { transforming power of the data set; } \\
& \lambda_{2}=\text { parameter to regulate the distribution fitting. }
\end{aligned}
$$

Twenty one values were selected for $\lambda_{1}$ inserted between the interval of $(-5,5)[11]$. The value of $\lambda_{1}$ selected for the transformation is that which provide the lowest value for $F_{\max }$. As the set of observed data occurs in the interval $(0,1)$, taking $\lambda_{2}=1$, it is possible to obtain values on a scale more favorable for the data transformation.

Due to stratification, an allocation of sample intensities became different per stratum and, consequently, with different degrees of freedom in each one of them; that is why it has been decided to use the Satterthwaite's method to calculate the number of degrees of freedom [12], as weighted mean and is presented in (3):

$$
n_{e}=\left(\sum_{h=1}^{L} g_{h} S_{h}^{2}\right)^{2}\left[\sum_{h=1}^{L} g_{h}^{2} S_{h}^{4}\left(n_{h}-1\right)^{-1}\right]^{-1} \quad g_{h}=\left[N_{h}\left(N_{h}-n_{h}\right)\right] n_{h}^{-1}
$$

where:

$n_{e}=$ weighted mean for the number of degrees of freedom;

$S_{h}^{2}=$ Variance per stratum;

$N_{h}=$ potential number of species $\left(E_{h}\right)$;

$n_{h}=$ number of species allocated per stratum; 
The value of $n_{e}$ must occur between the smallest of the values $\left(n_{h}-1\right)$ and shall not exceed their sum [13].

To carry out the statistical analysis between the strata means, it was applied the analysis of variance (ANOVA), whereas a completely randomized design with four treatments (strata) and different number of replicates, followed by application of Tukey's test, when identified significant statistical differences between strata means.

The methodology used to accomplish the prognoses was the ratio of moving diameters, used as a theory of stand projection tables applied to native forests [5]. Succinct manner, the application of such methodology consists in the migration of the number of trees to upper diameter classes, in function of the average diameter growth per class, considering the increases and decreases from recruitments and mortalities (Table 1). This model has been used successfully in prognosis works in native forests in Brazil, with best results than those obtained with the application of the Markov Chain model [14]. The data employed for stratification refer to the sampling period from 2000 to 2004.

With the purpose to verify the effect of stratification on the results of the prognosis, it was first predicted the forest structure, employing the stratified data and, subsequently, it was held the prognosis with the raw data, without stratification. Both prognoses were made for the year 2008. The forecasted values were compared with the observed ones by application of the Kolmogorov-Smirnov test $(K-S)$ at $95 \%$ probability, whose null hypothesis $\left(H_{0}\right)$ consists in goodness of fit between projected and observed data.

Complementary to the goodness of fit test, due to its importance in structural evaluations and in the effectiveness of the forest management practices, it was evaluated the behavior of the De Liocourt Quotient $(q)$ between the estimated and observed values.

\section{Discussion of the Results}

As population of species was defined $E(1,2,3, \cdots, 66)$, of which the random variable $X_{i}$ was calculated $(\overline{M P I})$, such that these mean values became associated with all species of the population $E\left(X_{1}, X_{2}, X_{3}, \cdots, X_{66}\right)$ with arithmetic mean $\left(\bar{X}_{M P I}\right)$ and variance $\left(S_{M P I}^{2}\right)$.

The stratification of diameter growth was established taking as criterion the quartiles based on the average growth of the species $\left(\bar{X}_{M P I}\right)$ and the standard deviation $\left(S_{M P I}\right)$. In this way, the population $E$ of the species was fractionated into 4 strata, such that each one of them was delimited as $N_{1}=8 ; N_{2}=29 ; N_{3}=18$ and $N_{4}=11$.

The periodic mean diameter increment $(\overline{M P I})$ for the forest was $\bar{X}_{M P I}=0.127 \mathrm{~cm} \cdot$ year $^{-1}$, a value lower than the average of $0.210 \mathrm{~cm} \cdot$ year $^{-1}$ found by Figueiredo Filho et al. in its bibliographical searches related to studies conducted in the Araucaria Forest [15]. The difference between the values found for increment can be explained, because the diameter growth is interpreted as a response to the availability of essential factors in the en-

\begin{tabular}{|c|c|c|c|c|c|c|}
\hline Center of class $(\mathrm{cm})$ & Number of trees & Movement ratio ${ }^{1}$ & Remaining $(\%)^{2}$ & Mortality $^{3}$ & Recruitment ${ }^{4}$ & Prognosis \\
\hline 15 & 2863 & 9.5733 & 90.4266 & 311 & 419 & 2696.9 \\
\hline 25 & 1251 & 11.9912 & 88.0087 & 70 & & 1031.1 \\
\hline 35 & 589 & 13.0108 & 86.9891 & 26 & & 486.5 \\
\hline 45 & 333 & 14.4637 & 85.5362 & 16 & & 269.0 \\
\hline 55 & 233 & 18.9068 & 81.0932 & 5 & & 184.2 \\
\hline 65 & 117 & 18.0459 & 81.9540 & 1 & & 95.2 \\
\hline 75 & 61 & 20.5915 & 79.4084 & 1 & & 47.8 \\
\hline 85 & 21 & 16.8126 & 83.1873 & 0 & & 17.9 \\
\hline 95 & 9 & 18.6129 & 81.3870 & 0 & & 7.6 \\
\hline 105 & 8 & 22.5408 & 77.4591 & 0 & & 7.1 \\
\hline
\end{tabular}

${ }^{1}$ indicates the ratio of the average growth by the width of the diameter class; ${ }^{2}$ trees that remained in the same class; ${ }^{3,4}$ number of trees that died and were recruited, respectively, during the observed period. 
vironment [16] [17], plus the characteristics related to different stages of forest succession in a phytogeographical unit.

Taking as basis for stratifying the average growth rate $\left(\bar{X}_{M P I}=0.127 \mathrm{~cm} \cdot\right.$ year $\left.^{-1}\right)$ and the standard deviation between the species $\left(S_{M P I}=0.071 \mathrm{~cm} \cdot\right.$ year $\left.^{-1}\right)$, the limits of the strata were defined as: $E_{1}$ for the values of $\bar{X}_{M P I} \leq 0.056 \mathrm{~cm} \cdot$ year $^{-1} ; E_{2}$ for values of $0.056 \mathrm{~cm} \cdot$ year $^{-1} \leq \bar{X}_{M P I} \leq 0.127 \mathrm{~cm} \cdot$ year $^{-1} ; E_{3}$ for the values of $0.127 \mathrm{~cm} \cdot$ year $^{-1} \leq \bar{X}_{M P I} \leq 0.198 \mathrm{~cm} \cdot$ year $^{-1}$ and $E_{4}$ for the values of $\bar{X}_{M P I} \geq 0.198 \mathrm{~cm} \cdot$ year $^{-1}$, as shown in Table 2.

The stratum of greater representativeness was the $E_{2}$, corresponding to $44 \%$ of the species evaluated, followed by $E_{3}$ (27\% of species), $E_{4}$ (17\% of species) and $E_{1}$ (12\% of species). The growth mean values of the respective strata were: $\bar{X}_{E_{1}}=0.030 \mathrm{~cm} \cdot$ year $^{-1} ; \quad \bar{X}_{E_{2}}=0.087 \mathrm{~cm} \cdot$ year $^{-1} ; \bar{X}_{E_{3}}=0.162 \mathrm{~cm} \cdot$ year $^{-1} ; \bar{X}_{E_{4}}=0.241 \mathrm{~cm} \cdot$ year $^{-1}$.

The variance for the population without stratification resulted in $S_{M P I}^{2}=0.00495\left(\mathrm{~cm} \cdot \mathrm{year}^{-1}\right)^{2}$, a value nine times higher than the stratified variance $S_{\text {est }}^{2}=0.00055\left(\mathrm{~cm} \cdot \operatorname{year}^{-1}\right)^{2}$. The strata 1 to 4 presented variances of: $S_{1}^{2}=0.00027\left(\mathrm{~cm} \cdot \text { year }^{-1}\right)^{2} ; S_{2}^{2}=0.00043\left(\mathrm{~cm} \cdot \text { year }^{-1}\right)^{2} ; S_{3}^{2}=0.00039\left(\mathrm{~cm} \cdot \text { year }^{-1}\right)^{2}$ and $S_{4}^{2}=0.00148\left(\mathrm{~cm} \cdot \text { year }^{-1}\right)^{2}$. Consequently, groups of greater growth homogeneity were obtained with the application of stratification inside the total population.

Each stratified data set followed the normal distribution, evaluated by the Shapiro-Wilk test $(W)$ at $95 \%$ probability. The effective number of degrees of freedom calculated by Satterthwaite's method was $41\left(n_{e}=40.4\right)$. The variances were not homogeneous (heteroscedasticity), with rejection of the null hypothesis $H_{0}$ by Hartley's test $\left(F_{\text {calc }}=5.49>F_{\text {tab;0.01 }}=2.97\right)$. The data set was then subjected to Box-Cox's transformation, with a value of $\lambda_{1}$ equal to -3.5 , which led to the lowest value for $F_{\text {calc }}$, ensured the homogeneity of variances $\left(F_{\text {calc }}=2.58<\right.$

\section{Table 2. Stratification of diameter growth by species in Araucaria Forest $(E)$.}

$$
E_{1}\left(X_{h} \leq 0.056 \mathrm{~cm} \cdot \text { year }^{-1}\right) N_{1}=8 W_{1}=0.12
$$

Acca sellowiana (O. Berg) Burret (0.007); Symplocos uniflora (Pohl) Benth. (0.014); Myrrhinium atropurpureum Schott (0.018); Myrcianthes gigantea (Cambess.) O. Berg (0.027); Dasyphyllum spinescens (Less.) Cabrera (0.035); Campomanesia rhombea O. Berg (0.037); Myrcia oligantha O. Berg (0.050); Eugenia uruguayensis Cambess. (0.052)

$$
E_{2}\left(0.056 \mathrm{~cm} \cdot \text { year }^{-1} \leq \bar{X}_{\text {IPD }} \leq 0.127 \mathrm{~cm} \cdot \text { year }^{-1}\right) \quad N_{2}=29 W_{2}=0.44
$$

Xylosma pseudosalzmannii Sleumer (0.058); Eugenia involucrata DC. (0.063); Pilocarpus pennatifolius Lem. (0.064); Lonchocarpus campestris Mart. ex Benth. (0.065); Myrceugenia miersiana (Gardner) D. Legrand \& Kause (0.065); Myrceugenia cucullata D. Legrand

(0.067); Roupala Montana Aubl. (0.068) Sebastiania brasiliensis Spreng. (0.070); Xylosma tweedianum (Clos) Eichler) (0.070); Machaerium paraguariense Hassl. (0.074); Calyptranthes concinna DC. (0.075); Eugenia psidiiflora O. Berg (0.075) Siphoneugena reitzii D. Legrand (0.078); Scutia buxifolia Reissek (0.078); Annona rugulosa (Schltdl.) H. Rainer (0.079); Myrciaria floribunda (H. West ex Willd.) O. Berg (0.081); Myrcianthes pungens (O. Berg) D. Legrand (0,083); Campomanesia xanthocarpa O. Berg (0.087); Citronella gongonha (Mart.) R.A. Howard (0.097); Sapium glandulosum (L.) Morong (0.098); Podocarpus lambertii Klotzsch ex Endl. (0.098); Lithraea brasiliensis Marchand (0.102); Sebastiania commersoniana (Baill.) L.B. Sm. \& Downs (0.111); Myrsine umbellata Mart. (0.112); Luehea divaricata Mart. \& Zucc. (0.114); Maytenus evonymoides Reissek (0.118); Myrsine coriacea (Sw.) R. Br. ex Roem. \& Schult (0.121); Ilex dumosa Reissek (0.121); Eugenia subterminalis DC. (0.123)

$$
E_{3}\left(0.127 \mathrm{~cm} \cdot \text { year }^{-1} \leq \bar{X}_{I P D} \leq 0.198 \mathrm{~cm} \cdot \text { year }^{-1}\right) \quad N_{3}=18 W_{3}=0.27
$$

Blepharocalyx salicifolius (Kunth) O. Berg (0.131); Inga vera Kunth (0.133); Casearia decandra Jacq. (0.136); Casearia obliqua Spreng. (0.143) Dasyphyllum tomentosum (Spreng.) Cabrera (0.147); Myrsine sp. (0.150); Araucaria angustifolia (Bertol.) Kuntz (0.152); Cryptocarya aschersoniana Mez (0.160); Ilex microdonta Reissek (0.162); Ocotea porosa (Nees \& Mart.) Barroso (0.163); Cryptocarya moschata Nees \& C. Mart. (0.167); Zanthoxylum rhoifolium Lam. (0.167); Solanum sanctae-catharinae Dunal (0.168); Dicksonia sellowiana Hook. (0.175); Ocotea pulchella Mart. (0.182); Ilex brevicuspis Reissek (0.184); Zanthoxylum petiolare A. St.-Hil. \& Tul. (0.196); Allophylus edulis (A. St.-Hil., Cambess. \& A. Juss.) Radlk. (0.196)

$$
E_{4}\left(\bar{X}_{I P D} \geq 0.198 \mathrm{~cm} \cdot \text { year }^{-1}\right) N_{4}=11 W_{4}=0.17
$$

Cupania vernalis Cambess. (0.197); Prunus myrtifolia (L.) Urb. (0.207); Ilex paraguariensis A. St.-Hil (0.209); Laplacea acutifolia (Wawra) Kobuski (0.215); Matayba elaeagnoides Radlk. (0.225); Lonchocarpus nitidus (Vogel) Benth. (0.231); Lamanonia ternata Vell. (0.233); Ocotea puberula (Rich.) Nees (0.256); Vernonanthura discolor (Spreng.) H. Rob. (0.265); Nectandra megapotamica (Spreng.) Mez (0.289); Cinnamomum glaziovii (Mez) Kosterm. (0.322) 
$\left.F_{t a b ; 0.01}=2.97\right)$ and remained normally distributed. Consequently, detected heteroscedasticity of the variances within strata in which the total population of $(\overline{M P I})$ was allocated, the application of Box and Cox transformation, using the prospective simulation proposed by Draper and Smith to identify the most appropriate root to be used in the process, resulted in total efficiency to get homoscedasticity of variances (Figure 1).

By means of analysis of variance, it can be observed that there are statistical differences between the strata (Table 3). Therefore, it is inferred that the auto ecological characteristics of each species that composes the plant community favor decisively the formation of groups with different diameter growth. Consequently, the stratification of diameter growth reduced the variance nine times, enabling the formation of groups of greater homogeneity and statistically different between themselves.

The Tukey's test indicated statistical differences between means of the strata (Table 4). Assuming that the differences between strata represent species with different growth potential, the choice of species belonging to a particular stratum may favor the accomplishment of the objectives of forest management, where growth has an important meaning. Consequently, the allocation of species in strata favors the decisions in forestry projects, in which the diameter increment is one of the relevant variables for the establishment of activities and delineation of targets.

Whereas the models of production meets a set of criteria that assist in decision making for the forest planning [18], it was evaluated the prognosis of the diametric structure from the stratified data and without stratification, by means of the methodology of ratio of change, which is based on diameter's growth and migration of them between diameter classes, unlike the Markov chain, which considers only the enumeration of individuals that move between classes. The predicted values in each stratum and total, which represents the sum of stratified estimates, are presented in Figure 2.

Meyer et al. in their studies that support the sustainable management, about the diameter distribution in hete-

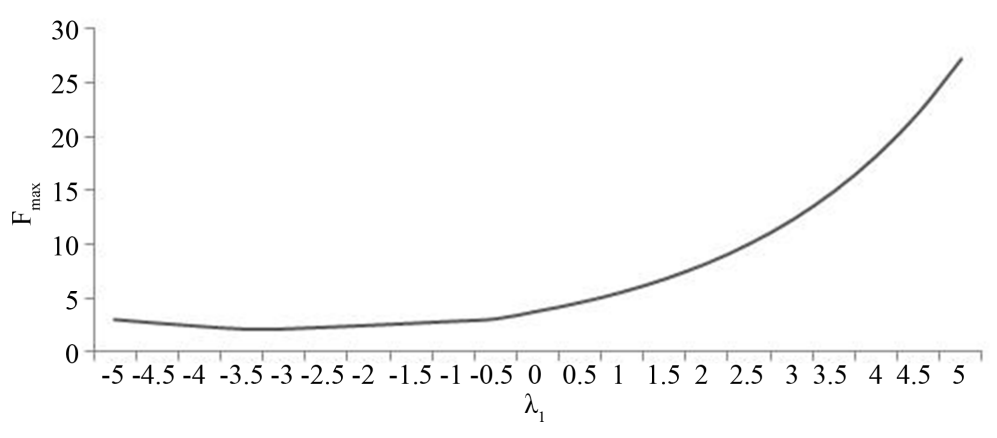

Figure 1. Behavior of the value $F_{\max }$ as a function of the values of $\lambda_{1}$ tested.

Table 3. Analysis of variance for stratification in Araucaria Forest.

\begin{tabular}{cccccc}
\hline$F V$ & $G L$ & $S Q$ & $Q M$ & $F_{\text {calc }}$ & $F_{\text {crit } 99 \%}$ \\
\hline Between strata & 3 & 0.123062 & 0.041020 & $180.22^{* *}$ & 2.75 \\
Within the strata & 62 & 0.014112 & 0.000227 & & \\
Total & 65 & 0.137173 & & & \\
\hline
\end{tabular}

${ }^{* *}$ Significant at $1 \%$ level of probability.

Table 4. Tukey’s test at 95\% probability between the strata means.

\begin{tabular}{ccccc}
\hline \multirow{2}{*}{ Strata } & \multicolumn{3}{c}{ Means } \\
\cline { 2 - 5 } & Transformed & Retransformed & Observed & \\
\hline$E_{1}$ & -0.25082 & 0.02937 & 0.03000 & $\mathrm{a}^{*}$ \\
$E_{2}$ & -0.19736 & 0.08569 & 0.08672 & $\mathrm{~b}$ \\
$E_{3}$ & -0.14600 & 0.16089 & 0.16178 & $\mathrm{c}$ \\
$E_{4}$ & -0.10932 & 0.23798 & 0.24082 & $\mathrm{~d}$ \\
\hline
\end{tabular}

${ }^{*}$ Means followed by same letter do not differ from each other by Tukey’s test at 95\% probability. 


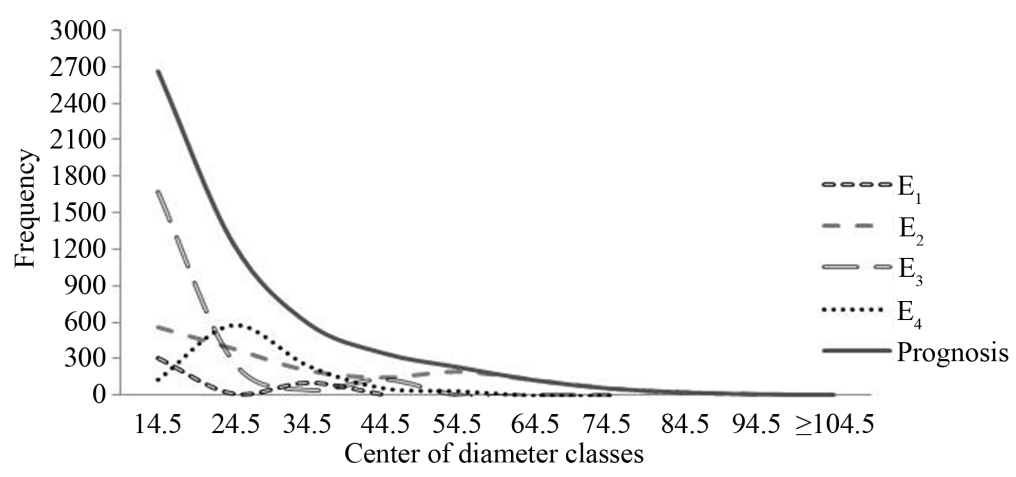

Figure 2. Projected frequency distribution per stratum and for the population.

rogeneous all age forests, refer to a pattern of decreasing exponential distribution to the extent to which diameter classes advance [19]. However, such a pattern was only found in the sum of stratified subpopulations, which generated the projected distribution. Each stratum presented differentiated settings in their distributions, justified by the auto ecological and synecological characteristics of the species of each stratum.

The $K$-S test $\left(D_{\text {calc }}=0.00949<D_{\text {tab; } 0.95}=0.01855\right)$ attested goodness of fit of projected values from stratified data, however the projected values from no stratified data did not present goodness of fit to the observed distribution $\left(D_{\text {calc }}=0.09826>D_{t a b ; 0.95}=0.01855\right)$. Therefore, results obtained with greater homogeneity between diameter growth values within strata tend to provide better estimates because the variations of growth between species are minimized with the group formation, allowing a refinement of estimates when using the results of the stratified parameters. This confirms our formulated hypotheses. The distributions of projected and observed frequencies are presented in Table 5.

De Liocourt considers that in a balanced forest, the diametric distribution in successive classes $(k)$ is derived from a constant geometric series called "Quotient of De Liocourt" $(q)$, essential parameter for the forest management proposal [20], in addition to structural evaluations of plant community. In perfect balanced forests $q$ assumes a constant value, indicating a pattern of decreasing exponential distribution in the forest [21].

The prognosis of the diametric structure, in these circumstances, in addition to estimate with accuracy the forest density, must maintain values equally accurate for obtaining the quotient $q$, indicating an approximate results for quotients of distribution of frequencies for the forest structure, which can be observed in Table 6.

In both projected distributions and in the observed one, the $q$ quotients, minimum and maximum, remained in the same classes, $k_{4} / k_{5}$ and $k_{7} / k_{8}$ respectively. The lowest accuracy between the projected and observed ratios was found in the estimation without stratification, for the lower and upper diameter classes, reaffirming what was observed in the distribution of frequencies. Generally speaking, disregarding the lower and the upper diameter classes without stratification, there is similarity between the estimated distributions and the observed one, essentially when performed with stratification. Consequently, the prognosis of diametric distribution for the year 2008 resulted more accurate when calculated from stratified data, evaluated by the goodness of fit attested at 95\% probability by the application of the Kolmogorov-Smirnoff test in relation to data observed in 2008; the same condition occurred in the evaluation of the Quotient of Liocourt (Figure 3).

Other methodologies can be developed to fit the models of prognosis, providing greater accuracy in their results. In heterogeneous forests, for example, it will be appropriate to separate groups formed by species or botanical families. The application of probability density functions can also improve the prognosis, favoring a distribution with greater similarity between estimated and observed values of the forest.

\section{Conclusions}

The auto ecological characteristics of each species that composes the plant community favor decisively the formation of groups with different diameter growth and the stratification of diameter growth reduced the variance nine times, enabling the formation of groups statistically different of greater homogeneity.

The stratification of diameter growth approached the predicted results to those observed in the sample population, allowing the forest manager to work with the best estimators in preparation of management proposals.

The methodology of ratio of change, which is based on diameter's growth and migration of them between 


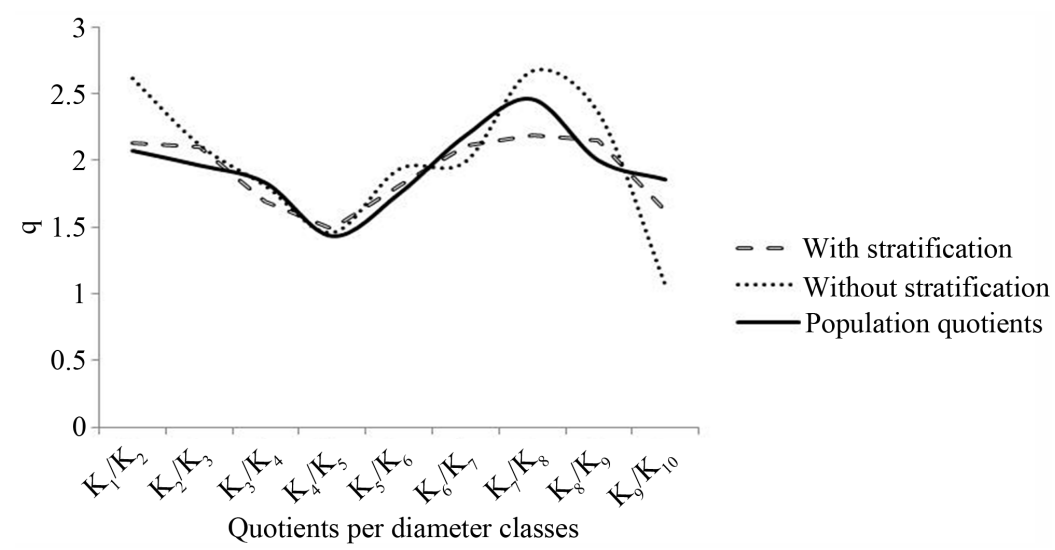

Figure 3. Distribution of De Liocourt quotients for observed and predicted values.

Table 5. Prognosis of the number of individuals per diameter class generated from the values with and without stratification, and observed values of the diametric distribution of Araucaria Forest, for the year 2008.

\begin{tabular}{cccc}
\hline Center class $(\mathrm{cm})$ & With stratification & Without stratification & N observed \\
\hline 14.5 & 2657.2 & 2696.9 & 2619 \\
24.5 & 1248.5 & 1031.1 & 1263 \\
34.5 & 592.9 & 486.5 & 643 \\
44.5 & 349.8 & 269.0 & 351 \\
54.5 & 234.9 & 184.2 & 245 \\
64.5 & 129.5 & 95.2 & 140 \\
74.5 & 61.2 & 47.8 & 64 \\
84.5 & 28.0 & 17.9 & 26 \\
94.5 & 13.0 & 7.6 & 13 \\
$\geq 104.5$ & 8.0 & 7.1 & 7 \\
$\sum$ & 5323.1 & 4843.2 & 5371 \\
\hline
\end{tabular}

Table 6. Values for the quotient of De Liocourt from the prognosis of diametric distribution and observed values of Araucaria Forest, for the year 2008.

\begin{tabular}{cccc}
\hline \multirow{2}{*}{ Classes } & \multicolumn{3}{c}{ Quotient of Liocourt $(q)$} \\
\cline { 2 - 4 } & With stratification & Without stratification & Population quotients \\
\hline$k_{1} / k_{2}$ & 2.13 & 2.62 & 2.07 \\
$k_{2} / k_{3}$ & 2.11 & 2.12 & 1.96 \\
$k_{3} / k_{4}$ & 1.69 & 1.81 & 1.83 \\
$k_{4} / k_{5}$ & 1.49 & 1.46 & 1.43 \\
$k_{5} / k_{6}$ & 1.81 & 1.93 & 1.75 \\
$k_{6} / k_{7}$ & 2.12 & 1.99 & 2.19 \\
$k_{7} / k_{8}$ & 2.19 & 2.67 & 2.46 \\
$k_{8} / k_{9}$ & 2.15 & 2.36 & 2.00 \\
$k_{9} / k_{10}$ & 1.63 & 1.07 & 1.86 \\
$\bar{q}$ & 1.92 & 2.00 & 1.95 \\
\hline
\end{tabular}

*Values obtained with all population data. 
diameter classes showed to be very efficient to make prognosis in native forests.

The prognosis of diametric distribution for the year 2008 resulted more accurately when calculated from stratified data, evaluated by the goodness of fit attested at $95 \%$ probability by the application of the Kolmogorov-Smirnoff test in relation to data observed in 2008.

The evaluation of the coefficient of De Liocourt behaved better in stratification using diameter growth by classes when compared to the results obtained without stratification.

\section{References}

[1] SFB—Serviço Florestal Brasileiro (2010) Florestas do Brasil em resumo-2010: Dados de 2005-2010. SFB, Brasília.

[2] Vanclay, J.K., Gillicon, A.N. and Keenan, R.J. (1997) Using Functional Attributes to Quantify Site Productivity and Growth Patterns in Mixed Forests. Forest Ecology and Management, 94, 149-163. http://dx.doi.org/10.1016/S0378-1127(96)03972-2

[3] Sanquetta, C.R., Angelo, H., Brena, D.A. and Mendes, J.B. (1995) Predição da distribuição diamétrica, mortalidade e recrutamento de floresta natural com matriz Markoviana de potência. Floresta, 24, 23-36.

[4] Péllico Netto, S. and Brena, D.A. (1997) Inventário Florestal. The Authors, Curitiba.

[5] Scolforo, J.R.S., Pulz, F.A. and Melo, J.M. (1998) Modelagem da produção, idade das florestas nativas, distribuição espacial das espécies e análise estrutural. In: Scolforo, J.R.S., Ed., Manejo Florestal, UFLA/FAEPE, Lavras, 189-206.

[6] de Souza, D.R., de Souza, A.L., Gama, J.R.V. and Leite, H.G. (2003) Emprego de análise multivariada para estratificação vertical de florestas inequiâneas. Revista Árvore, 27, 59-63. http://dx.doi.org/10.1590/S0100-67622003000100008

[7] Ferreira, W.C., Botelho, S.A., Davide, A.C. and Faria, J.M.R. (2007) Avaliação do crescimento do estrato arbóreo de área degrada revegetada à margem do Rio Grande, na usina Hidrelétrica de Camargos, MG. Revista Árvore, 31, 177185. http://www.scielo.br/scielo.php?script=sci arttext\&pid=S0100-67622007000100020 http://dx.doi.org/10.1590/S0100-67622007000100020

[8] USDA-Soil Survey Staff (1999) Soil Taxonomy-A Basic System of Soil Classification for Making and Interpreting Soil Survey. 2nd Edition, USDA, Washington DC.

[9] Kaul, P.F.T. (1990) Geologia. IBGE-Instituto Brasileiro de Geografia e Estatística. Região Sul. IBGE, Rio de Janeiro, 29-54.

[10] Fernandes, A.V. and Backes, A. (1998) Produtividade primária em floresta com Araucaria Angustifolia no Rio Grande do Sul. Iheringia Série Botânica, 51, 63-78.

[11] Draper, N.R and Smith, E. (1981) Applied Regression Analysis. 2nd Edition, John Wiley \& Sons Inc., New York.

[12] Satterthwaite, F.E. (1946) An Approximate Distribution on Estimates of Variance Components. Biometrics Bulletin, London, 2, 110-114. http://dx.doi.org/10.2307/3002019

[13] Cochran, W.G. (1963) Sampling Techniques. 2nd Edition, John Wiley \& Sons Inc., New York.

[14] Ebling, A.A., Watzlawick, L.F., Rodrigues, A.L., Longhi, S.J., Longhi, R.V. and Abrão, S.F. (2012) Acuracidade da distribuição diamétrica entre métodos de projeção em Floresta Ombrófila Mista. Ciência Rural, 42, 1020-1026. http://dx.doi.org/10.1590/S0103-84782012000600011

[15] Figueiredo Filho, A., Dias, A.N., Stepka, T.F. and Sawczuk, A.R. (2010) Crescimento, mortalidade, ingresso e distribuição diamétrica em Floresta Ombrófila Mista. Floresta, 40, 763-776.

[16] Zanon, M.L.B. and Finger, C.A.G. (2010) Relação de variáveis meteorológicas com crescimento das árvores de Araucaria angustifolia (Bertol.) O. Kuntze em povoamentos implantados. Ciência Florestal, 20, 467-476. http://cascavel.ufsm.br/revistas/ojs-2.2.2/index.php/cienciaflorestal/article/view/2061

[17] Pulz, F.A., Scolforo, J.R., de Oliveira, A.D., Mello, M.M. and de Oliveira Filho, A.T. (1999) Acuracidade da predição da distribuição diamétrica de uma floresta inequiânea com a matriz de transição. Cerne, 5, 1-14.

[18] Stepka, T.F., Dias, A.N., Figueiredo Filho, A., Machado, S.A. and Sawczuk, A.R. (2012) Modelagem do Incremento em diâmetro da Araucaria angustifolia em uma Floresta ombrófila Mista no Centro-Sul do Paraná. Floresta, 42, 607-620.

[19] Meyer, H.A., Reccknagel, A.B., Stevenson, D.D. and Bartoo, R.A. (1961) Forest Management. 2nd Edition, The Ronald Press Company, New York.

[20] Schneider, P.R. and Finger, C.A.G. (2000) Manejo sustentado de florestas inequiâneas heterogêneas. UFSM, Santa Maria.

[21] Imaña-Encinas, J., Santana, O.A., de Macedo, L.A. and de Paula, J.E. (2008) Distribuição diamétrica de um trecho da Floresta Estacional Semidecidual na área do Ecomuseu do Cerrado. Cerne, 14, 33-45. http://www.redalyc.org/articulo.oa?id=74414105 
Scientific Research Publishing (SCIRP) is one of the largest Open Access journal publishers. It is currently publishing more than 200 open access, online, peer-reviewed journals covering a wide range of academic disciplines. SCIRP serves the worldwide academic communities and contributes to the progress and application of science with its publication.

Other selected journals from SCIRP are listed as below. Submit your manuscript to us via either submit@scirp.org or Online Submission Portal.
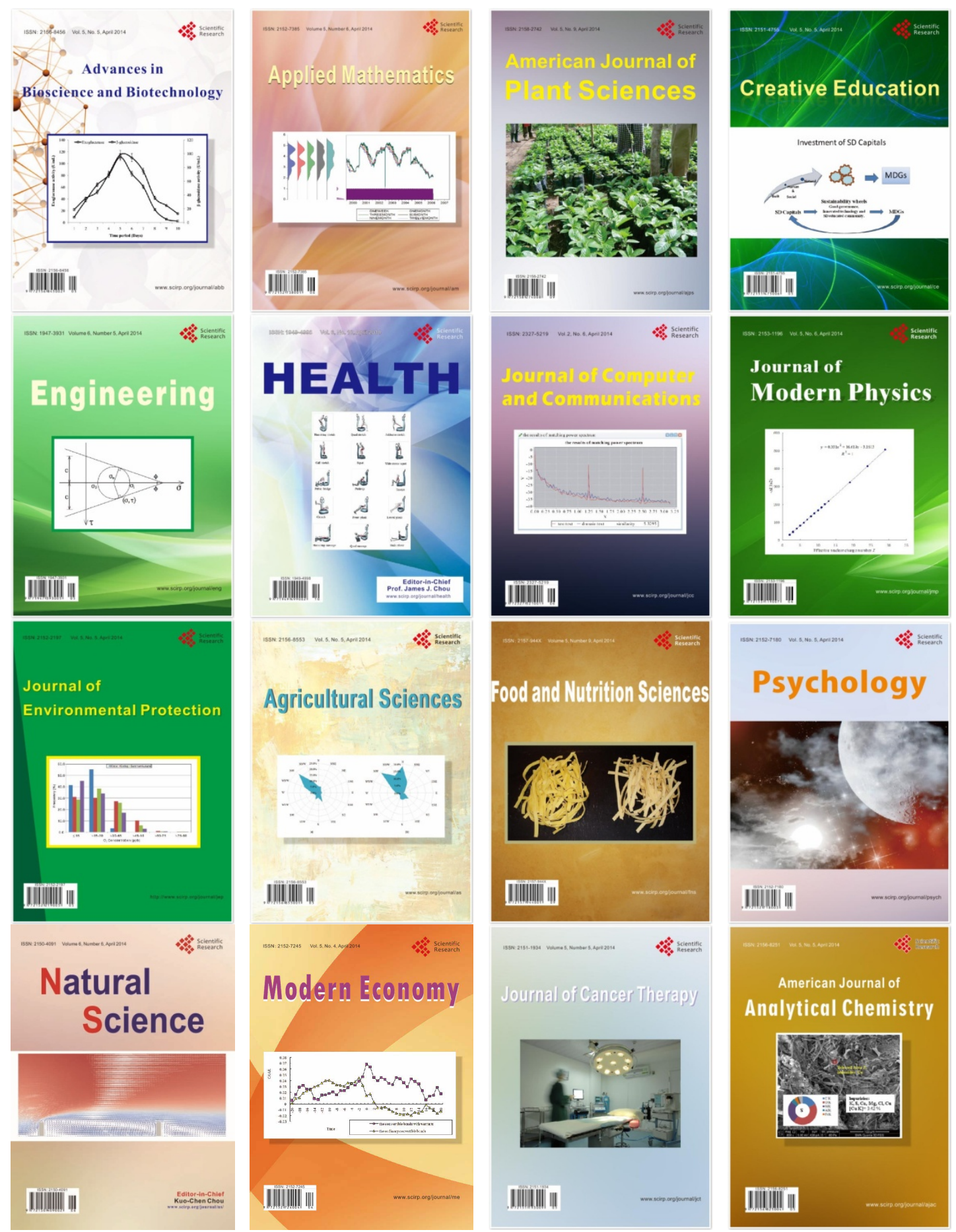